Open Access

\title{
Government policies and entrepreneurship phases in emerging economies: Nigeria and South Africa
}

\author{
Folashade O. Akinyemi* (D) and Oluwabunmi O. Adejumo
}

\author{
*Correspondence: oyediatob@ \\ yahoo.com; queenesthershade@ \\ gmail.com; akinyemifo@oauife.edu.ng \\ Institute for Entrepreneurship and \\ Development Studies, Obafemi \\ Awolowo Univeristy, lle-Ife, Nigeria
}

\begin{abstract}
This paper introduces entrepreneurship phases in studying the impact of some government policies on entrepreneurial activities. Entrepreneurship and small business development are the heart of many countries economy, and countries that give entrepreneurship special attention stand better chances of improved economy and industrialization. World over, it is well known that government policies often affect entrepreneurial activities directly and indirectly. But the question is do these policies have equal impact in every entrepreneurship phase. Hence, this study seeks to examine some policy factors that enhance entrepreneurial activities in two of African's emerging economies. And precisely, to identify the most favorable government policy in each entrepreneurship phase. This study was conducted in the economic hub of two African emerging economies (Nigeria and South Africa), where most entrepreneurial activities take place. A total of 1200 questionnaires (650 in Lagos, Nigeria and 550 in Johannesburg, South Africa) were administered. The analysis was in two stages; stage one involved descriptive statistics while stage two involved inferential statistics. Also, Principal Component Analysis (PCA) was used to identify the most favorable government policy in each entrepreneurship phase. The results show that some variations exist in the policy implementation approaches of both economies. The efficacies and shortcomings associated with the policies impacted entrepreneurial activities. The findings show that the impact of government policies on entrepreneurship phases differ in both countries. The study concluded that some policies are more favorable than others in some phases. Hence, makes a clarion call for more studies on government policies across entrepreneurship phases.
\end{abstract}

Keywords: Government policies, Entrepreneurship phases, Emerging economies

\section{Introduction}

The popular picture of "the praying hands", which originated from the real-life experience of two brothers, Albrecht and Albert (Desy, 2018), brings to fore the fact that man, no matter how talented and endowed he is, would always need a helping hand. Similarly, entrepreneurs cannot make it alone. They need support from both internal and external sources: from family members, institutions, and governments. Otherwise, their dreams may never materialize. And their lofty ideas may never come to fusion unless certain measures are put in place.

(c) The Author(s). 2018 Open Access This article is distributed under the terms of the Creative Commons Attribution 4.0 International License (http://creativecommons.org/licenses/by/4.0/), which permits unrestricted use, distribution, and reproduction in any medium, provided you give appropriate credit to the original author(s) and the source, provide a link to the Creative Commons license, and indicate if changes were made. 
The argument is that though entrepreneurs possess some traits and characteristics that make them dynamic and high achievers, government policies affect their activities directly and indirectly. Also, research has shown that government policies relating to taxes and business regulations often affect entrepreneurial activities (Acs \& Szerb, 2007; Bygrave \& Timmons, 1992; Kreft \& Sobel, 2005). The taxes, tariffs, and monetary policies have rippling effects on entrepreneurial activities. When government, for instance, decides to mop up funds from the economy, they sell treasury bills to the public. This invariably reduces the money in circulation, affect investors' willingness to release funds, and ultimately cripple entrepreneurial activities. On the other hand, when money is pumped into the economy, more funds are made available for investments and entrepreneurial activities.

Entrepreneurship and small business development are the heart of many countries economy and any country giving its entrepreneurs special attention has a better chance of an improved economy. In recognition of the need for entrepreneurship policies, many countries have implemented both general and specific policies to promote entrepreneurial activities. General policies such as tax rates, labour laws, and market regulations have shaped the entrepreneurship climate to a great extent in different economies. Also, some specific policies have been specially targeted to promote entrepreneurship. For instance, the Small Business Innovation Research (SBIR) program established in America increased the survival and growth rates of SMEs in the region (Gilbert, Audretsch, \& McDougall, 2004; Lerner \& Kegler, 2000). In Europe, the Department for Trade and Industry (DTI) develop policies to promote entrepreneurial activities and encourage SMEs to trade internationally (Wright, Westhead, \& Ucbasaran, 2007; Curran, 2000).

In developing nations also, entrepreneurship policies have been implemented to promote entrepreneurial activities. In Taiwan, for instance, policy measures such as the establishment of industrial parks, Industrial Technology Research Institute (ITRI), and local industrial clustering, have enhanced entrepreneurial vitality (Lin, Chang, \& Shen, 2010). The Small Business Act of the Republic of South Africa (RSA, 1996) was promulgated to promote entrepreneurial activities in South Africa (Ladzani \& Van Vuuren, 2002; Nieman, 2001). In Nigeria, structures and programmes such as the Small and Medium Enterprises Development Agency (SMEDAN), N-Power programme, Government Enterprise and Empowerment Programme (GEEP) and the You-win programme were designed to promote entrepreneurial activities by facilitating access to funds and other resources needed for SMEs (Oliyide, 2012; Today.ng, 2018). All these policies and much more are targeted towards promoting entrepreneurship. But the question that comes to mind is "Do all these government policies and programs have equal effects on all entrepreneurship phases?"

Numerous studies have shown that government policies affect entrepreneurial activities but there is the need to examine government policies across entrepreneurship phases. This paper, therefore, seeks to examine some general government policies in emerging economies, and identify the policies that best promote entrepreneurial activities in the entrepreneurship phases of two emerging economies in Africa.

\section{Literature review}

Theoretically, entrepreneurs are known to possess some characteristic traits that make them high achievers and unique. Basically, the concept of entrepreneurship is rooted in 
cognitive or trait theory, and microeconomic theory. Cognitive theory focuses on identifying needs and taking risks to combine resources in order to meet the needs. In other words, it describes how individuals with certain traits are able to identify gaps in the society and fill the gaps. It also describes how some unique traits enable entrepreneurs to conduct business activities profitably, withstand pressure, overcome challenges, break barriers, and produce goods and services that better the lives of citizens.

Microeconomic theory, on the other hand, focuses in details on resources allocation and utilization among individual components of the economy. It describes how resources are efficiently allocated, and utilized in order to make profit and avoid wastage. For instance, the decisions of entrepreneurs about what to produce, how to produce, where to produce, and what prices to charge, are contained in microeconomic theory, which can be linked to the resource and management factors needed for business growth and development. These two theories, combined together, describe the fundamental activities carried out by individuals who efficiently allocate and utilise available resources, and take risks in order to create value and develop the society.

However, despite their unique traits, entrepreneurs need enabling environment in order to thrive well. For instance, Adams Smith's (1776) work on 'the wealth of nations' pointed out that liberal commercial policies promote nations' wealth. Countries that changed their policies from socialism to capitalism recorded increase in entrepreneurial activities (Acs \& Szerb, 2007). Adams pointed out that even the self-interest of entrepreneurs motivates them to set up businesses, some reform policies are needed to promote entrepreneurial activities in the land. And advocated for policy reforms such as abolition of local taxes and duties; free choice of occupation, free trading activities across borders; and repealing of laws that restrict free transfer of land. By extension, therefore, the capitalist theory enhances the economic as well as entrepreneurial activities.

\section{Government policies}

A policy can be defined as a plan of action agreed and chosen by a group of people, organization, or political party. In business, policies can be categorized as internal or external. The internal policies guide and spell out how business activities are run. The internal policies, also known as business policies, are set by the owners and management of a business, and determine their scope of operations (Oviatt \& McDougall, 2005). But these business policies are dependent and often influenced by the overall government policies within the economy in which entrepreneurs operate. The government policies therefore, are external policies which are not within the direct control of the entrepreneurs within the economy. Hence, this study focuses on the entrepreneurship policies made by governments.

Entrepreneurship policies are the plans or courses of action, established by government in order to influence and enhance entrepreneurial decisions and actions (Audretsch, Grilo, \& Thurik, 2007; Vesper, 1983; Klapper, Amit, \& Guillén, 2010). Government policies in this sense, refers to rules and regulations that enable the startup and viability of entrepreneurial activities. Some policies are targeted to specific businesses while others affect entrepreneurs directly. For instance, in Nigeria, agro allied businesses are often exempted from tax during the first five years of operation (Ngerebo \& Masa, 2012; Odusola, 2006). Some businesses are also being subsidized 
while small businesses enjoy tax exemption. Also, policies implemented to discourage the importation of manufactured goods often protect indigenous industries and encourage entrepreneurial activities.

\section{Effect of government policies on entrepreneurship}

Governments establish many rules and regulations that guide businesses. Businesses would normally adapt their operations to changes in government policies, rules and regulations. Government economic policy and market regulations have an influence on the competitiveness and profitability of businesses. Business owners must comply with regulations established by federal, state and local governments. The government can implement a policy that changes the social behavior in the business world. For example, the government can levy taxes on the use of carbon-based fuels and grant subsidies for businesses that use renewable energy. The government can underwrite the development of new technology that will bring the necessary change. Imposing on a particular sector more taxes or duties than are necessary will make the investors lose interest in that sector. Similarly, tax and duty exemptions on a particular sector trigger investment in it and may generate growth. A high tax rate on imported goods, for example, may encourage local production of the same goods. And on the other hand, a high tax rate for raw materials would hamper domestic production.

The impacts of government policies on developed economies have been reflective in literature. Government Policies in the United Kingdom helped Cadbury in the mid 1850s when the taxes on imported cocoa beans were reduced (Fitzgerald, 2005; Cadbury World, 2014). This reduced the production costs, and the previously expensive chocolate products became affordable for the wider population. Also, to further discourage the use of adulterated foods and beverages at that time, the Parliament heralded Cadbury's unadulterated cocoa essence. This was another breakthrough for Cadbury, and led to the passing of the Adulteration of Foods Acts in 1872 and 1875 (Fitzgerald, 2005). As a result, Cadbury received a remarkable amount of free publicity, sales increased dramatically, and Cadbury broke the French producers' monopoly in the British market.

According to a research by the Global Entrepreneurship and Development Institute (Global Entrepreneurship Development Index, 2014), USA is a world leader in supporting its entrepreneurs with respect to business formation, expansion and growth. They also finance new businesses through venture capital. This type of financial capital is provided to early-stage, high potential and risk start-up companies. Countries like Canada and Australia ranked second and third, respectively. These countries' economies rank very high because they understand the impact of entrepreneurship on the growth of their economy, and make deliberate efforts to promote entrepreneurship.

Government policies are numerous but for this study, policies such as taxes, labour laws, trade regulations, and registration process were considered. This is because entrepreneurial activities in the two emerging economies are majorly small and medium scale cadre (Ligthelm, 2005; Ligthelm, 2006; Larossi \& Clarke, 2011; Ene \& Ene, 2014). And these policies affect entrepreneurship directly. Labour laws like the federal minimum wage, mandated benefits, duration of service, safety regulations, and restrictions on layoffs and firing determine the overall cost of production. Fair and effective trade 
regulations, however, protect and promote entrepreneurial activities. Trade regulations standardize and affect domestic trade, foreign exchange, and international trade (Aliyu, 2010; Ezedinma, 2008; Bolaky \& Freund, 2004; Bolaky \& Freund, 2004; Bhala, 1996; Oyejide, 1986), which invariably impact entrepreneurial activities. Also, removing the bottlenecks in business registration process, and providing some start-up capital, does enhance business activities (Bowale \& Akinlo, 2012; Agboli \& Ukaegbu, 2006; Babajide, 2012; Abereijo, Adegbite, Ilori, Adeniyi, \& Aderemi, 2009; Fatai, 2011).

\section{Entrepreneurship phases}

The Global Entrepreneurship Monitor (GEM) divided the entrepreneurial process into four phases namely: the conception phase; the start-up phase; the persistence phase; and the established phase (Bosma \& Levie, 2010). The conception phase is when entrepreneurs are nursing the idea to start a business. The start-up phase is when the business starts, that is, the first year of operation. The persistence phase is also referred to as the survival stage. It is the stage whereby the entrepreneur has made good progress and gained some experience. The business is growing, salaries and wages are being paid, running expenses and other operational costs are being incurred for up to three and half years. The established phase is when the business is over three and half years old, and is doing well. The Fig. 1 shows the GEM's description of entrepreneurship phases otherwise known as the entrepreneurial process.

The discontinuation of business signifies the point at which entrepreneurs find it hard and impossible to continue their business ventures. Some circumstances arise which negatively affect businesses. It could either be due to natural disaster or circumstances beyond the entrepreneur's control, which in law, is described as the act of God. It could also be as a result of poor management practices, unavailability of resources, changes in consumers' preferences, or change of policies. However, entrepreneurs, who are very resilient and optimistic, decide to start all over again. This signifies the

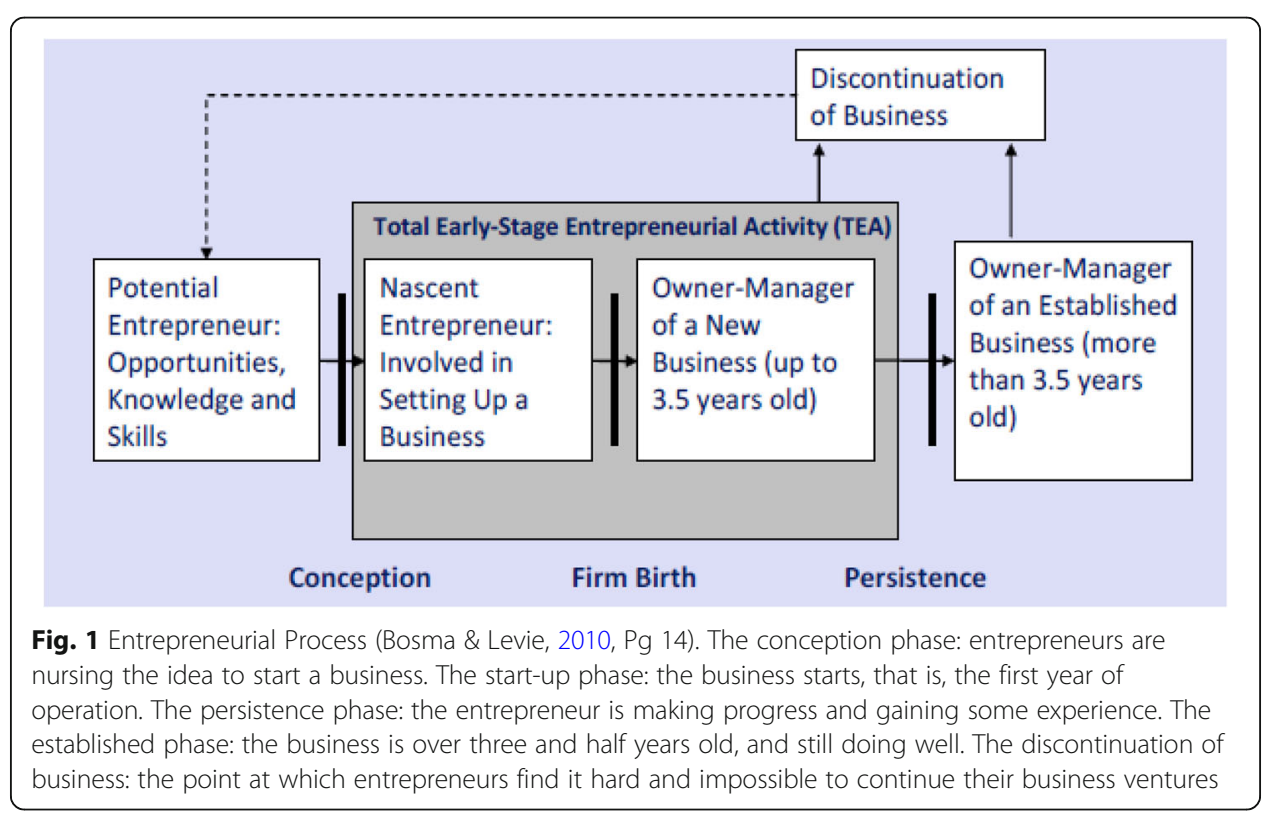


loop-back from the discontinuation of business to the potential entrepreneur level where new ideas are nursed. It stands for entrepreneurs who were once knocked out of the process, but came back on board.

However, some studies have shown some entrepreneurs go beyond the established phase. Some entrepreneurs remain in business for decades and continue to make significant impact. Some entrepreneurs mentor either a family member or an individual and pass on their businesses to their offspring or other entrepreneurs (Fattoum \& Fayolle, 2009; Bird, Welsch, Astrachan, \& Pistrui, 2004; Ward, 2004; Morris et al, 1997). Some businesses grow beyond borders. Some entrepreneurs build empires, and leave lasting legacies for generations to come (Arthur \& Hisrich, 2011; Zolin, 2012; Africa, 2006). Such entrepreneurs are said to have become renowned. Therefore for this study, five entrepreneurship phases as shown in Table 1 were examined. And the hypothesis to be tested is:

All the policy factors are equally helpful for all the entrepreneurship phases.

This implies that for all the identified phases, as samples are drawn from the population, all the phases are conveniently factored in our selection. Thus, based on the identified phase per business, the focus of government general policies on the day-to-day running of the sampled businesses are analyzed. With this, we can identify if all phases in different businesses, experience similar experience for the laid down policies guiding business operations in each country.

\section{Nexus between some government policies and entrepreneurship in Nigeria and South} Africa

According to the Corporate Affairs Commission (CAC) in Nigeria, there are articles for those interested in registering their business under Part B of the Companies and Allied Matters Act called Business Name Registration. A registered business name is either a general company, incorporated companies or incorporated trustees. However, given the nature of the large informal sector in Nigeria, the Small and Medium Enterprises Development Agency of Nigeria (SMEDAN) partnered with the CAC in order to fast tract business registration for Micro, small and Medium Enterprises (MSMEs), without needing a lawyer. This is done by having SMEDAN's desk representative CAC's offices of every State; while the CAC would also send its staff for capacity building like serving as resource persons during SMEDAN's Entrepreneurship Training Programmes [ETPs] to educate prospective and existing entrepreneurs on business registration issues.

No doubt legally registered business enjoy the benefit of legal entity and access to credits, nonetheless, several MSMEs in Nigeria have their businesses unregistered. Also, despite government efforts to increase participation through reduced cost and the

Table 1 Entrepreneurship Phases

\begin{tabular}{llll}
\hline & Entrepreneurship Phase & Duration of Business & Entrepreneur's Descriptor \\
\hline 1. & Conception & Nil & Latent \\
2. & Firm Birth & $0-1$ year & Nascent \\
3. & Persistence & $1-3.5$ years & Nascent Opportunity \\
4. & Established & $3.5-10$ years & Established \\
5. & Renowned & More than 10 years & Renowned \\
\hline
\end{tabular}


ability to register under a day, several businesses lie outside the formal registered business (SMEDAN Online: https://smedan.gov.ng/); hence depicting the ease of business start-ups in Nigeria. Once a business is registered in Nigeria, it is expected to pay tax. But due to the most SMEs lying outside the formal sector and the poor tax system many entrepreneurs find it easy to evade (Makinde, 2005; Kiabel \& Nwokah, 2009; Otusanya, 2010; Abiola \& Asiweh, 2012; Adebisi \& Gbegi, 2013). Empirical studies have identified some of the loopholes in governance and entrepreneurship development in Nigeria. Incidentally, unlike Multinationals and registered companies, these holes have aided the ease of business start-ups and growing businesses especially amongst SMEs (Agboli \& Ukaegbu, 2006).

This is unlike in South Africa where company registration can be herculean for new entrepreneurs or small business owners. In 2011, The Companies and Intellectual Property Registration Office (CIPRO) replaced the Companies and Intellectual Property Commission (CIPC) to see to registration of new businesses. Businesses can either fall into profit or non-profit organizations depending on its focus. The profit-making organizations can then take on the form of MSMEs, public or private company. Once a business is registered, it will then be registered automatically as a taxpayer. Newly established firms must register with local SARS office to obtain an income tax reference number. Once the business commences, everything that has to do with registration must be completed within 60 days. This organized and mandatory process of business registration has made it impossible for businesses to evade taxes. Small businesses with turnover of up to R1 million per annum have their tax payment procedure enhanced; where taxes like turnover tax, VAT and employees' tax are spread twice instead of once a year, making the process more efficient for qualifying small business owners (Online: https://www.smesouthafrica.co.za/The-basics-of-registering-a-new-small-business/).

Studies have shown that these mandatory conditions have been adduced as one of the challenges to start-ups and growth of MSMEs in South Africa (Olawale \& Garwe, 2010; Mbonyane \& Ladzani, 2011). However, there are also benefits of compliance with business registration to include business name protection, tax deductions, financial assistance and increasing your staff capacity.

\section{Methodology}

This study was conducted in the economic hub of two African emerging economies, Nigeria and South Africa. Lagos is Nigeria's commercial center where most entrepreneurial activities take place (Singh, Simpson, Mordi, \& Okafor, 2011; Tijani, Oyeniyi, \& Ogunyomi, 2012). It is in the South Western part of Nigeria, and the most populous city in Nigeria. Similarly, Johannesburg is South Africa's commercial center where most entrepreneurial activities take place (Urban, 2009; Callaghan \& Venter, 2011). It is the largest city in South Africa and is the provincial capital of Gauteng.

The target population comprises of entrepreneurs in emerging economies (Nigeria \& South Africa). The sample size consists of entrepreneurs in Lagos and Johannesburg. A total of 1200 copies of questionnaires were administered. And since the estimated figures obtained through extant literature revealed that there are more entrepreneurs in Lagos than in Johannesburg, 550 copies of questionnaires were administered in Johannesburg and 650 in Lagos. Convenience Sampling technique was used to select the respondents, after which they were then stratified into the five entrepreneurship phase identified in the 
extant literature. However, 535 and 598 copies of questionnaires were retrieved in Johannesburg and Lagos, respectively, and analyzed. This comprises adults between 18 and 64 years as adopted by the Global Entrepreneurship Monitor (Kelley, Singer, \& Herrington, 2011). The five entrepreneurship phases identified in the extant literature were well represented, with at least $20 \%$ of the respondents representing each phase. The survey sample reflected a sufficiently broad representation of entrepreneurs in Nigeria and South Africa. Meanwhile, the focal policies of the government for this study are market regulations, business registration, taxation and labour laws.

This study was conducted in strict compliance with social research ethics such as voluntary consent, anonymity, and confidentiality. For construct validity, the key concepts were properly defined and the operational measures identified. Cronbach's Alpha was used to test for reliability (Cronbach, 1951; Santos, 1999; Bhattacherjee, 2012). The instruments were also pre-tested to ensure that the contents were well understood.

Respondents were asked to select the level of importance of each of the four policy factors based on a five-point scale of most very crucial, crucial, somewhat crucial, slightly crucial, and not crucial. Using Principal Component Analysis (PCA), the responses were then analysed based on the entrepreneurship phases identified in the extant literature. Principal Component Analysis (PCA) is a descriptive statistical technique used to simplify the description of a data set by extracting the most important information therein (Bro \& Smilde, 2014; Abdi \& Williams, 2010; Wold, Esbensen, \& Geladi, 1987). PCA is often used to identify the most crucial among the groups of factors. Similarly, in this study, PCA is used to search for importance among the policies, and also as a data reduction method. The Kaiser-Meyer-Olkin (KMO) statistics confirm the appropriateness of applying a PCA for the study. It also measures sampling adequacy for each variable in the model and for the complete model. The variances represent the percentage values that each group of sustainability factors account for in the data set.

Thus, the data collected were cleaned and analysed using STATA. PCA was used to identify the most crucial policy factor(s) in each entrepreneurship phase, Also, Chi-square test was used to show the association between the variables, and Cronbach's Alpha was employed to test the internal consistency and reliability of some of the critical indicators.

\section{Results and discussion}

In order to establish if the policy factors for the entrepreneurship phases in emerging economies are similar or not, the first step was to examine some general government policies enhancing entrepreneurial activities in each entrepreneurship phase, and then identify the most crucial. Section 4.1 presents the basis for the analysis by presenting the reliability coefficients of the research findings and effects of the policies on the entrepreneurship phases. The next section (4.2) addresses the first objective by presenting various policies enhancing entrepreneurial activities in each entrepreneurship phase.

\section{Distribution Pattern \& Statistical Significance}

The respondents were asked to rank the policy factors enhancing their businesses. The bar charts in Fig. 2 show the frequencies of the policies enhancing businesses, in the 


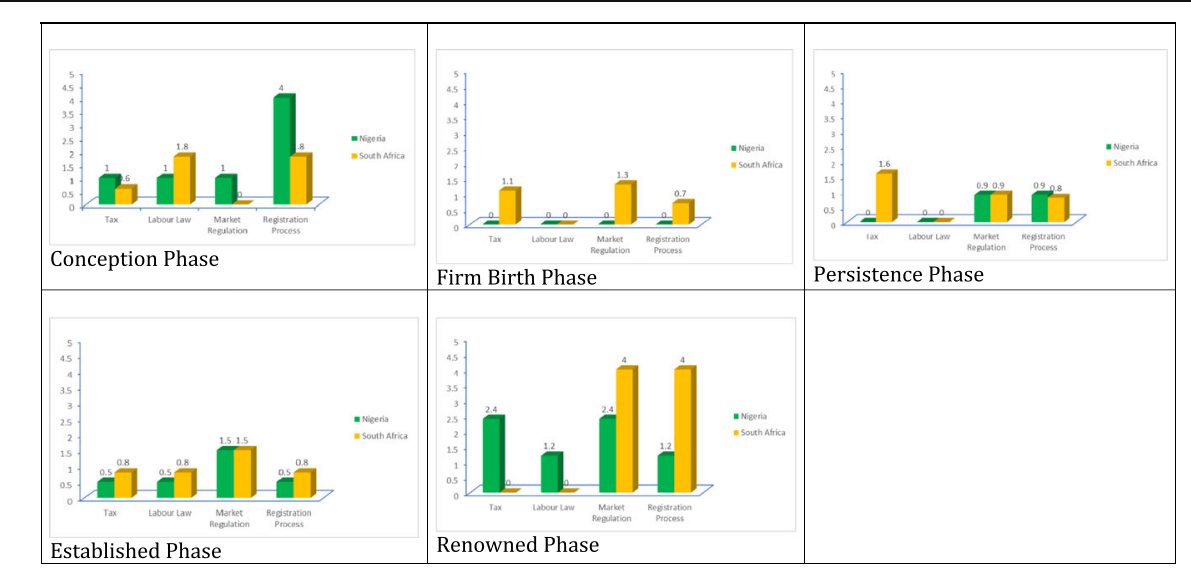

Fig. 2 Government Policies That Enhance Entrepreneurship Phases in Nigeria and South Africa. The green bars show the frequencies of government policies enhancing businesses in the entrepreneurship phases in Nigeria. The yellow bars show the frequencies of government policies enhancing businesses in the entrepreneurship phases in South Africa

entrepreneurship phases in Nigeria and South Africa. This literarily implies that the policies that enhance entrepreneurial activities in these economies are not the same. Some factors are more prominent in some phases than others as shown in Table 2. These findings are further confirmed in the next level of analysis.

Table 3 presents the bivariate distribution of the policies with emphasis on both the distribution pattern and statistical significance of each variable within the domain. As shown in Table 3, without controlling for business sectors or entrepreneurship phases, all the variables were statistically significant $(p<0.05)$ across the two countries and for the combined data set. Statistical significance is always represented by a lowercase $p$, and stands for probability. Hence, $p<.05$ means that the probability of these results being a fluke is less than 1 in 20 times which has been the agreed upon level of chance, for researches in the social sciences, that results can be wrong.

For this study, the statistical significance highlights the relative importance of the policies adopted in each business sector and entrepreneurship phase. A major striking point in Table 3 is the fact that the aggregate measures of the policy factors align with the literature review sections where all the factors were reported as important for entrepreneurial development. The previous studies, flagging the importance of these policies, were conducted independently, at different points in time, and were not specific about the levels where these policies are more pivotal. Hence, without controlling for phases, the holistic view is that all the policies are equally significant. But when entrepreneurship phase are introduced, as shown in Appendix IV, interesting insights are obtained.

Table 2 Most Prominent Government Policies in each Entrepreneurship Phase

\begin{tabular}{llll}
\hline No & Phases & Nigeria & South Africa \\
\hline 1 & Conception & Registration Process & Registration Process \& Labour Law \\
2 & Firm birth & - & Market Regulations \\
3 & Persistence & Market Regulations \& Registration Process & Tax \\
4 & Established & Market Regulations & Market Regulations \\
5 & Renowned & Market Regulations \& Tax & Market Regulations \& Registration Process
\end{tabular}


Table 3 Cross-Tabulation of Policies in Nigeria and South Africa

\begin{tabular}{|c|c|c|c|c|c|c|}
\hline \multirow[t]{2}{*}{ Sectors } & \multicolumn{2}{|l|}{ Nigeria $(n=598)$} & \multicolumn{2}{|c|}{ South Africa $(n=535)$} & \multicolumn{2}{|c|}{ Both Countries $(n=1133)$} \\
\hline & Percent/p-value & Chi-square & percent/p-value & Chi-square & percent/p-value & Chi-square \\
\hline \multicolumn{7}{|l|}{ Policy } \\
\hline $\operatorname{Tax}$ & $0.7^{*}$ & 53.62 & $1.1^{*}$ & 10.01 & $0.9^{*}$ & 39.59 \\
\hline Labour Law & $0.5^{*}$ & 53.61 & $0.4^{*}$ & 9.99 & $0.4^{*}$ & 39.56 \\
\hline Market Regulation & $1.2^{*}$ & 53.65 & $1.1^{*}$ & 10.01 & $1.2^{*}$ & 39.61 \\
\hline Registration Process & $1.2^{*}$ & 53.65 & $0.9^{*}$ & 10.00 & $1.1^{*}$ & 39.60 \\
\hline
\end{tabular}

${ }^{*}$ significant at $p<.05$

Considering the holistic distribution patterns in Table 3, market regulation and registration process are the most helpful policies in Nigeria. In South Africa, tax and market regulation were the most helpful while registration process was the most helpful in the pooled data. This suggests that, the entrepreneurs in both emerging economies attested to the fact that, the improvements in the registration process in both economies did enhance their businesses. The findings are consistent with the GEM (2017) report on South Africa. For instance, on a scale of $1-9$, moving from highly insufficient to insufficient, South Africa had 4.77 in government policies supporting entrepreneurial activities; thus indicating a moderately sufficient level. However, the GEM reports a low level (2.73) of sufficiency in terms of taxes and bureaucracy. Thus, indicating a less flexible system for entrepreneurs to thrive.

Although GEM did not present any report on Nigeria, "Doing Business Report" (DBR) 2018 findings confirm the ease of doing business in Nigeria with regard to business registration and the payment of taxes. The DBR also reports a more stringent condition for business in South Africa, especially in terms of business registration and tax payment. While the South African economy makes it easy to use online platforms available to check business names, the bureaucracy of business registration is still a little complicated. Also, their taxes are costly especially in terms of vehicle and property tax rates. Therefore, the complicated means of paying taxes is evident in the length of time it takes to prepare VAT returns, thereby making business and entrepreneurship activities less flexible (Doing Business Report, 2018).

\section{Factor Loadings \& Reliability Coefficients of policy factors}

Factor loadings represent how much a factor explains a variable in factor analysis. The Loadings can range from -1 to 1 . Loadings close to -1 or 1 indicate that the factor strongly affects the variable negatively or positively, respectively. Loadings close to zero indicate that the factor has a weak effect on the variable being measured. For this study, the loadings represent the strength of the policy factors in each entrepreneurship phase and economy. Hence, factors with values such as 0.8 or 0.9 indicate that the policies have strong effects on the phases and economies under consideration.

Cronbach's alpha $(\alpha)$, on the other hand, is a measure of internal consistency; that is, how closely related a set of items is as a group. It is considered to be a measure of scale reliability, that is, it measures whether several items that propose to measure the same general construct produce similar scores. The Cronbach's alpha in this research findings show how closely related the policies are. It also shows the average covariance between 
each group, and the variance of the total score. Generally, researchers recommend a minimum $\alpha$ coefficient between 0.65 and 0.8 (or higher in some cases); $\alpha$ coefficients that are less than 0.5 are usually unacceptable. So, an alpha value of 0.83 or 0.75 , for instance, implies that the policies in each group are closely related, and that they adequately measure what they were meant to measure. Thereby confirming the reliability of the results.

Generally, in both countries, all the four variables recorded high factor loadings, with reliability coefficient greater than 0.5 . In Nigeria, business registration process had the highest factor loading of 0.7 while in South Africa; labour law had the highest factor loading of 0.8. For both countries, however, labour law and registration process had the highest factor loading of 0.7. This implies that most of the policy factors have strong effects on the entrepreneurial activities in both economies and further confirm previous findings in the extant literature. The details are presented in Table 4 and consistent with DBR findings on the flexibility of business registration and labour laws in Nigeria as well as its importance on business activities. For instance, the DBR shows that labour market regulations are more standardized in South Africa than in Nigeria. For instance, while proper remuneration of work value is ensured in South Africa, the reverse is the case in Nigeria. For instance, the South African economy has a provision for unemployment protection after one year, while in Nigeria the unemployment protection policy is not often enforced (Doing Business Report, 2018).

\section{Background information on sampled entrepreneurs and businesses}

In terms of the gender of business ownership in both countries, the bulk of the enterprises were owned by male (63\% in Nigeria and 62\% in South Africa). The median age of the sampled entrepreneurs was very close in both countries (31 years in Nigeria compared with 32 years in South Africa). The age distribution leaned favourably towards the younger age range of 18-33 years constituting relatively more than half of the sampled entrepreneurs (53\% in Nigeria and 51\% in South Africa). More than one-fourth are aged $34-41$ years, and only about 6\% in Nigeria and 7\% in South Africa were aged 50 years or more.

About $27 \%$ of entrepreneurs sampled in Nigeria and 34\% of those sampled in South Africa had a university degree, only $2 \%$ of entrepreneurs in Nigeria and about $10 \%$ in South Africa had a post-graduate degree. Relatively among the sampled individuals,

Table 4 Internal Structure and Domain of Policies in Nigeria and South Africa

\begin{tabular}{|c|c|c|c|c|c|c|}
\hline \multirow[t]{2}{*}{ Two Countries } & \multicolumn{2}{|l|}{ Nigeria } & \multicolumn{2}{|l|}{ South Africa } & \multicolumn{2}{|c|}{ Both Countries } \\
\hline & $\begin{array}{l}\text { Factor } \\
\text { loading }\end{array}$ & Alpha/Variance & Factor loading & Alpha/Variance & $\begin{array}{l}\text { Factor } \\
\text { loading }\end{array}$ & Alpha/Variance \\
\hline \multicolumn{7}{|l|}{ Policy } \\
\hline Tax & 0.6 & & 0.6 & & 0.6 & \\
\hline Labour Law & 0.6 & 0.67 & 0.8 & 0.62 & 0.7 & 0.65 \\
\hline Trade Regulation & - & 82.3 & 0.5 & 82.0 & 0.5 & 80.2 \\
\hline $\begin{array}{l}\text { Registration } \\
\text { Process }\end{array}$ & 0.7 & & 0.7 & & 0.7 & \\
\hline
\end{tabular}

Factor loadings only depicted if 0.5 or more in the sub-scales. The internal consistency measured with Cronbach's alpha and explained variance as presented in the same column 
those in South Africa showed a higher proportion of those with at least a university degree than their counterparts from Nigeria. This is not surprising because, a large percentage of the business owners in Lagos are Ibos who would rather learn a trade and go straight into business, than get a degree in college.

Nigeria is a multi-lingual country with over 250 languages but has three official languages; Yoruba, Igbo, and Hausa. Nigeria is also known for its cultural diversities, but largely dominated by three main languages; the Yorubas in the west, Igbos in the East, and Hausas in the North.

Furthermore, the five entrepreneurship phases were represented in both economies as shown in Table 5 Another striking feature of the distribution is that although more samples were drawn from Nigeria, yet South Africa had higher percentage of entrepreneurs in some phases than Nigeria. Among the sampled individuals, Nigeria had more entrepreneurs at the conception, established, and renowned phases than those sampled in South Africa. And South Africa had more entrepreneurs at the firm birth and persistence phases.

\section{Distribution pattern and statistical significance of government policies across phases}

The results in Table 6 suggest that South Africa recorded more significant policy factors than Nigeria. This portrays South Africa's entrepreneurial development as requiring more efforts for survival than Nigeria. At conception phase, all the policy factors in South Africa were statistically significant. Implying that the entrepreneurs in South Africa need the proper implementation of all the policy factors in order to make it to the firm birth phase whereas their counterparts in Nigeria only need one of the policy factors (that is, registration requirement) in order to make it to the firm birth phase.

At firm birth phase, none of the policy factors were significant in both countries. At the persistence and established phases, none of the policy factors were significant in Nigeria whereas in South Africa, all the policy factors were significant. This implies that the policies in South Africa have significant impact on, and are enhancing, their entrepreneurial activities whereas in Nigeria, the impact of the policies are negligible and often not felt (Chukwuemeka, 2011). Most of the Nigerian entrepreneurs are pushing through and trying to survive despite the poorly implemented policies in the country (Mary, Enyinna, \& Ukpai, 2015). At the renowned phase, however, none of the policy factors were significant. This is understandable because at this phase, the entrepreneurs are well grounded and most of their businesses are self-sustaining.

\section{Helpful policy factors in each entrepreneurship phase}

Having confirmed that the policy factors are not equally enhancing entrepreneurial activities in all the five phases, the next step was to examine their relative importance in order to identify the most crucial policy factor(s) in each entrepreneurship phase. For both economies, the results showed the Eigen-values of the various combinations of policy factors in each phase, but when analyzed separately, the findings varied across countries. As shown in Table 6, the Kaiser-Meyer-Olkin (KMO) statistics confirm the appropriateness of applying a PCA for the study. It also measures sampling adequacy for each variable in the model and for the complete model. The variances represent the 
Table 5 Characteristics of Sampled Entrepreneurs in Nigeria and South Africa

\begin{tabular}{|c|c|c|c|c|}
\hline \multirow[t]{2}{*}{ Variables } & \multicolumn{2}{|l|}{ Nigeria } & \multicolumn{2}{|l|}{ South-Africa } \\
\hline & $\begin{array}{l}\text { Frequency } \\
N=609\end{array}$ & Percent & $\begin{array}{l}\text { Frequency } \\
N=539\end{array}$ & Percent \\
\hline \multicolumn{5}{|l|}{ Gender } \\
\hline Male & 385 & 63.2 & 336 & 62.3 \\
\hline Female & 224 & 36.8 & 203 & 37.7 \\
\hline \multicolumn{5}{|l|}{ Age in Years } \\
\hline $18-24$ & 80 & 13.3 & 65 & 12.1 \\
\hline $25-33$ & 238 & 39.6 & 209 & 38.9 \\
\hline $34-41$ & 159 & 26.5 & 155 & 28.8 \\
\hline $42-49$ & 87 & 14.5 & 70 & 13.0 \\
\hline $50-57$ & 24 & 4.0 & 27 & 5.0 \\
\hline $58-65$ & 13 & 2.2 & 12 & 2.2 \\
\hline Median Age & 31.2 years & & 32.4 years & \\
\hline \multicolumn{5}{|l|}{ Academic Qualification } \\
\hline Below First Degree & 421 & 71.0 & 299 & 56.1 \\
\hline First Degree & 162 & 27.3 & 183 & 34.3 \\
\hline Masters & 8 & 1.4 & 43 & 8.1 \\
\hline $\mathrm{PhD}$ & 2 & 0.3 & 8 & 1.5 \\
\hline \multicolumn{5}{|l|}{ Nationality } \\
\hline Nigeria & 589 & 97.9 & 90 & 17.7 \\
\hline South Africa & 5 & 0.8 & 280 & 54.9 \\
\hline Other & 13 & 2.4 & 168 & 31.2 \\
\hline \multicolumn{5}{|l|}{ Religion } \\
\hline Christianity & 474 & 77.9 & 407 & 75.5 \\
\hline Islam & 122 & 20.0 & 47 & 8.7 \\
\hline Others & 13 & 2.1 & 83 & 15.4 \\
\hline \multicolumn{5}{|l|}{ Entrepreneurship Phase } \\
\hline Conception & 106 & 17.41 & 87 & 16.14 \\
\hline Firm Birth & 110 & 18.06 & 165 & 30.61 \\
\hline Persistence & 109 & 17.90 & 129 & 23.93 \\
\hline Established & 200 & 32.84 & 133 & 24.68 \\
\hline Renowned & 84 & 13.79 & 25 & 4.64 \\
\hline
\end{tabular}

percentage values that the policy factors account for in the data set. Values greater than $60 \%$ are generally acceptable in social science research.

Eigen-values indicate the strength or relative length of variables in a data set. They explain the degrees of importance of the variables in a data set. Eigen-values of more than 0.5 are typically considered strong. Eigen-values between 0.3 and 0.5 are acceptable while Eigen-values less than 0.3 are typically considered weak. Hence, for this study, the policy factor with the highest Eigen-value, in each entrepreneurship phase, was selected as the most helpful policy factor in that phase (see Table 7).

The results show that the policies enhancing entrepreneurial activities in emerging economies are different. Also, that the policies needed to boost entrepreneurial activities are peculiar to each economy, and different across phases. And as such, any prospective entrepreneur or investor, seeking to set up businesses in these economies, 
Table 6 Cross Tabulation of Government Policies in Nigeria \& South Africa

\begin{tabular}{|c|c|c|c|c|}
\hline & \multicolumn{2}{|l|}{ Nigeria } & \multicolumn{2}{|l|}{ South Africa } \\
\hline & Percent/ $p$-value & Chi-square & Percent/ $p$-value & Chi- square \\
\hline \multicolumn{5}{|l|}{ Conception Phase } \\
\hline Tax & 0.9 & 2.89 & $0.0^{*}$ & 112.40 \\
\hline Labour Law & 0.9 & 3.27 & $1.2^{*}$ & 114.10 \\
\hline Trade Regulation & 0.9 & 2.75 & $0.0^{*}$ & 112.50 \\
\hline Registration Process & $3.7^{*}$ & 10.65 & $1.2^{*}$ & 112.20 \\
\hline \multicolumn{5}{|l|}{ Firm Birth Phase } \\
\hline Tax & 0.0 & 1.64 & 1.8 & 2.00 \\
\hline Labour Law & 0.0 & 0.66 & 0.0 & 1.91 \\
\hline Trade Regulation & 0.0 & 1.64 & 1.2 & 1.01 \\
\hline Registration Process & 0.0 & 0.18 & 0.6 & 1.29 \\
\hline \multicolumn{5}{|l|}{ Persistence Phase } \\
\hline Tax & 0.0 & 0.91 & $1.6^{*}$ & 14.51 \\
\hline Labour Law & 0.0 & 0.69 & $0.0^{*}$ & 15.07 \\
\hline Trade Regulation & 0.9 & 0.10 & $0.8^{*}$ & 14.60 \\
\hline Registration Process & 0.9 & 0.10 & $0.8^{*}$ & 14.42 \\
\hline \multicolumn{5}{|l|}{ Established Phase } \\
\hline Tax & 0.5 & 0.38 & $0.8^{*}$ & 12.50 \\
\hline Labour Law & 0.5 & 0.26 & $0.8^{*}$ & 12.70 \\
\hline Trade Regulation & 1.5 & 0.57 & $1.5^{*}$ & 12.33 \\
\hline Registration Process & 0.5 & 1.39 & $0.8^{*}$ & 12.29 \\
\hline \multicolumn{5}{|l|}{ Renowned Phase } \\
\hline Tax & 2.3 & 4.43 & 0.0 & 2.56 \\
\hline Labour Law & 1.2 & 0.96 & 0.0 & 2.33 \\
\hline Trade Regulation & 2.4 & 1.30 & 4.0 & 4.07 \\
\hline Registration Process & 1.2 & 0.01 & 4.0 & 4.77 \\
\hline
\end{tabular}

*significant at $p<05$

must take cognizance of the peculiarities in each economy in order to enjoy the maximum benefits therein. This section, also, addresses the hypothesis stated in Section 2.3, that all the four policy factors are equally helpful in all the entrepreneurship phases, and describes the principal component analysis results in Table 6.

At conception phase, the pooled data for both countries and South Africa had market regulations (0.962 and 0.997) as the most favorable factor. Meaning that the market regulation policies were favourable in both countries. Market regulations such as Open market policies, domestic trade, foreign exchange policies promote entrepreneurial activities. In Nigeria, however, tax (0.968) was the principal factor. This is not surprising because the poor tax administration process in Nigeria (Makinde, 2005; Otusanya, 2010; Adebisi \& Gbegi, 2013) has created loopholes for SMEs to evade tax payments. As a result, entrepreneurs worry less about tax payment, and as a result plough back the income into their business. At firm birth phase, South Africa and the pooled data for both economies had the same principal factor, market regulations (0.999 and 0.986). But in Nigeria, tax (0.999) was still the principal component like it was at conception phase.

At persistence phase, the principal factors were dissimilar as registration process (0.943) was the principal factor for the pooled data. Whereas tax (0.988) was the 
Table 7 Principal Component Analysis of Policies across Entrepreneurship Phases in Nigeria and South Africa

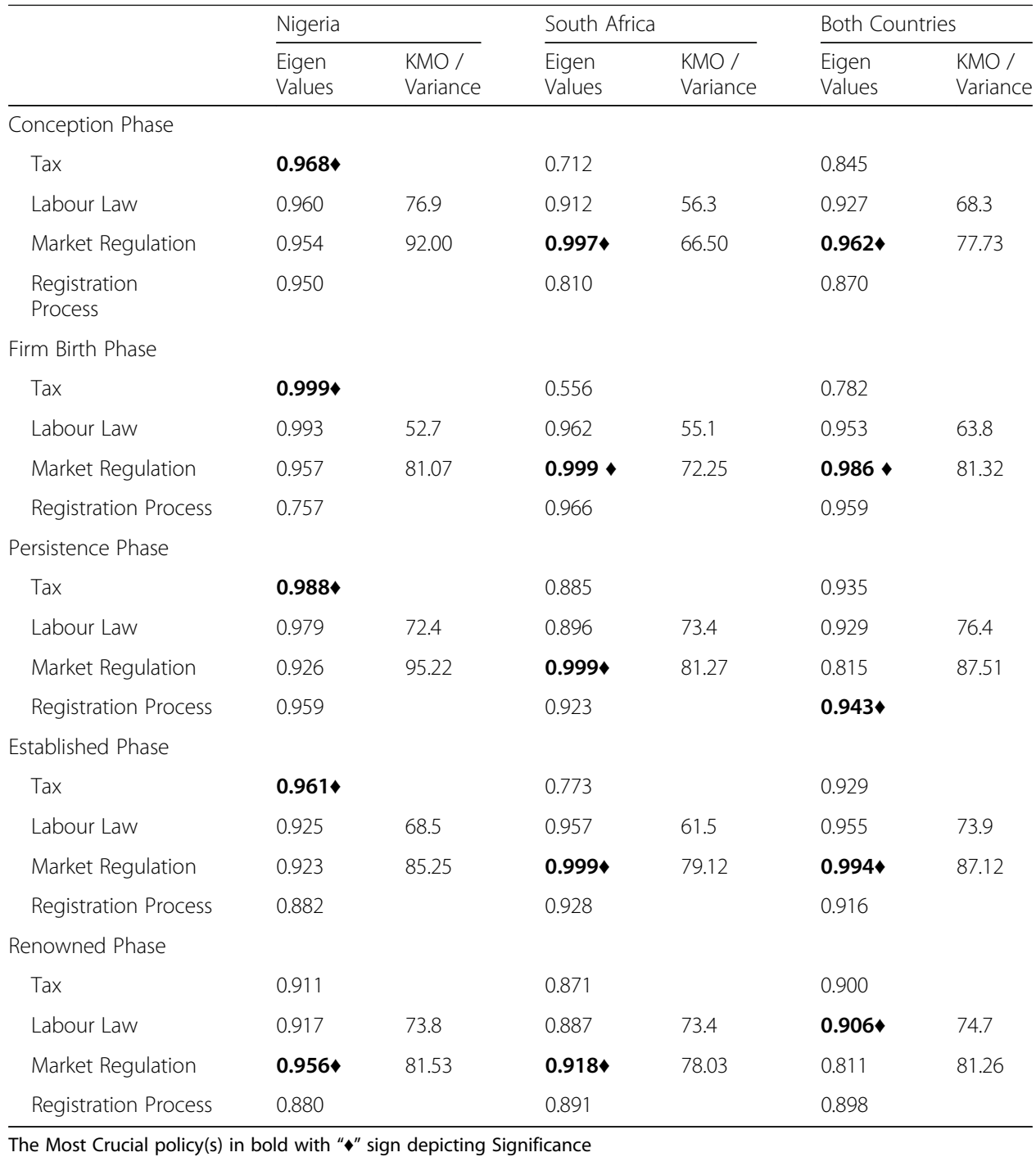

principal factor in Nigeria, while market regulation (0.999) was the principal factor in South Africa. Recently, in both economies, the registration process have been enhanced such that the bottle necks and bureaucratic processes have been reduced to the barest minimum.

At the established phase, market regulation (0.994 and 0.999) was the principal component for both economies and South Africa while Nigeria had tax (0.961) as its principal policy factor. And at renowned phase, Nigeria and South Africa had market regulation (0.956 and 0.918 respectively) as their principal component but labour law was the principal component for the pooled data. This imply that the labour law in both countries appear to be more flexible as regards labour cost; thus enhancing entrepreneurial activities.

From Table 7, the prominence of tax as the principal component in the first four phases indicates that the loopholes in the tax administration policy in Nigeria is so obvious, and serves as an advantage to entrepreneurs. Whereas, in South Africa, the 
prominence of market regulation in all the five phases indicates that the market regulation policies are favourable in promoting entrepreneurial activities. This position in South Africa is not farfetched; given the fallouts from the abolishment of apartheid regime and the standardized market policies.

\section{Conclusion}

The general inference drawn from this study is that policy factors that enhance entrepreneurial activities differ across entrepreneurship phases. The findings confirm that government policies do not have equal impact on all the entrepreneurship phases. Some policies are more favourable in some phases than others. Hence, entrepreneurs, relevant stakeholders and policy makers need to take cognizance of the inherent disparities in the effects of policies implemented on entrepreneurial activities from time to time. This further connotes, therefore, that policy makers seeking to effectively promote entrepreneurship could target specific phases at specific times in order to boost the entrepreneurial activities in such phases.

Finally, this paper is a clarion call for more studies on the impact of government policies on entrepreneurship phases, especially for specific businesses and sectors of the economy. The researchers also advocate for studies that would examine the impact of some specific policies and special interventions on each entrepreneurship phase.

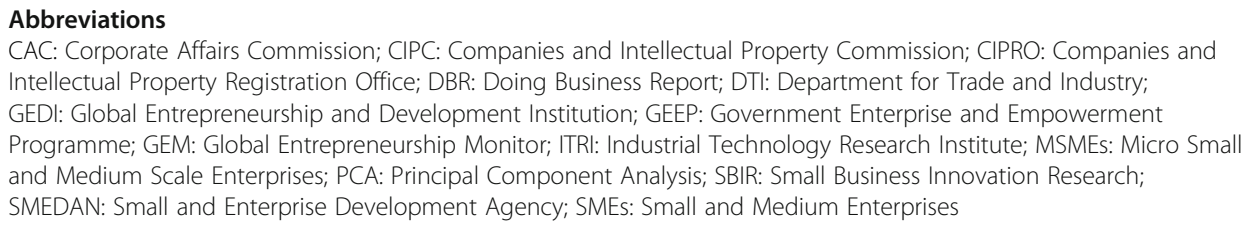

Acknowledgements

Not applicable.

Funding

There is currently no funding source for this study.

\section{Availability of data and materials}

The data set generated and analyzed during the current study are not publicly available because the data is a segment of a larger survey and is currently being used for further studies. However, the dataset is available from the corresponding author on reasonable request.

\footnotetext{
Authors' information

Akinyemi Folashade Oyeyemi is a Researcher and Lecturer at the Institute For Entrepreneurship \& Development Studies (IFEDS), Obafemi Awolowo University, lle-lfe. She is an alumnus of high ranking universities in Nigeria (Obafemi Awolowo University) and South Africa (University of the Witwatersrand).

She has received various trainings in Nigeria and abroad. She had her Bachelor Degree and two Masters Degree at Obafemi Awolowo University and bagged her PhD at the University of the Witwatersrand, Johannesburg. She has presented papers and posters at Local \& International Conferences. She has also published articles in reputable Journals and Book Chapters in the areas of Small \& Medium Scale Enterprises, Family Businesses, Entrepreneurship Development, and Retirement Planning. Adejumo O. O. is presently a Lecturer/Researcher at Obafemi Awolowo University. She obtained her Bachelors, Masters and Doctoral degree from the Obafemi Awolowo University, lle-lfe, Nigeria. She has also been engaged in short-course training programme nationally and internationally. Her research efforts has concentrated issues pertaining to development issues, including human capital development and sustainable development. She has participated in divers Academic Research \& Developmental project aimed at scaling up entrepreneurship and vocational skills acquisition for undergraduates and she is also directly involved in Business Development Consultancy Services for companies and corporate organization.
}

\section{Authors' contributions}

Both Authors were involved in the preparation of the manuscript. Both authors read and approved the final manuscript. 


\section{Publisher's Note}

Springer Nature remains neutral with regard to jurisdictional claims in published maps and institutional affiliations.

\section{Received: 27 February 2018 Accepted: 29 November 2018}

Published online: 17 December 2018

\section{References}

Abdi, H., \& Williams, L. J. (2010). Principal component analysis. Wiley Interdisciplinary Reviews: Computational Statistics, 2(4), 433-459.

Abereijo, I. O., Adegbite, S. A., Ilori, M. O., Adeniyi, A. A., \& Aderemi, H. A. (2009). Technological innovation sources and institutional supports for manufacturing small and medium enterprises in Nigeria. Journal of Technology Management \& Innovation, 4(2), 82-89.

Abiola, J., \& Asiweh, M. (2012). Impact of tax administration on government revenue in a developing economy-a case study of Nigeria. International Journal of Business and Social Science, 3(8).

Acs, Z. J., \& Szerb, L. (2007). Entrepreneurship, economic growth and public policy. Small Business Economics, 28(2-3), 109-122.

Adebisi, J. F., \& Gbegi, D. O. (2013). Effect of tax avoidance and tax evasion on personal income tax administration in Nigeria. American Journal of Humanities and Social Sciences, 1(3), 125-134.

Africa, L. (2006). Defying the Odds: Case Studies of Nigerian Organizations that Have Survived Generations: Kachifo limited.

Agboli, M., \& Ukaegbu, C. C. (2006). Business environment and entrepreneurial activity in Nigeria: Implications for industrial development. The Journal of Modern African Studies, 44(1), 1-30.

Aliyu, S. U. R. (2010). Exchange rate volatility and export trade in Nigeria: An empirical investigation. Applied Financial Economics, 20(13), 1071-1084.

Arthur, S. J., \& Hisrich, R. D. (2011). Entrepreneurship through the ages: Lessons learned. Journal of Enterprising Culture, 19, 1-40.

Audretsch, D. B., Grilo, I., \& Thurik, A. R. (2007). Explaining entrepreneurship and the role of policy: A framework. In The handbook of research on entrepreneurship policy (pp. 1-17). Edward Elgar Publishing.

Babajide, A. (2012). Effects of microfinance on micro and small enterprises (MSEs) growth in Nigeria. Asian Economic and Financial Review, 2(3), 463

Bhala, R. (1996). International trade law. Theory and Practice (2 e éd., 2001, Lexis Publishing), 594-604.

Bhattacherjee, A. (2012). Social Science Research: Principles, methods, and practices (2nd Edition.): USF Tampa Bay Open Access Textbooks Collection. Book 3.

Bird, B., Welsch, H., Astrachan, J. H., \& Pistrui, D. (2004). Family business research: The evolution of an academic field. Family Business Review, 15(4), 337-350

Bolaky, B., \& Freund, C. L. (2004). Trade, regulations, and growth. World Bank Policy Research Working Paper No. 3255. Available at SSRN: https://ssrn.com/abstract=610296.

Bosma, N., \& Levie, J. (2010). Global entrepreneurship monitor, 2009 global Report (pp. 8-16).

Bowale, E. I., \& Akinlo, A. (2012). Determinants of small and medium scale enterprises (SMEs) performance and poverty alleviation in developing countries: Evidence from south-West Nigeria. European Journal of Humanities and Social Sciences, 17(1), 848-863

Bro, R. \& Smilde, A. K. (2014). Principal component analysis. Analytical Methods, 6(9), 2812-2831.

Bygrave, W. D., \& Timmons, J. (1992). Venture capital at the Crossroads Retrieved from https://scholar.google.com Cadbury World (2014). History of Cadbury. Retrieved from www.englishteastore.com and https://www.cadbury.co.uk/our-story

Callaghan, C., \& Venter, R. (2011). An investigation of the entrepreneurial orientation, context and entrepreneurial performance of Inner-City Johannesburg street traders. Southern African Business Review, 15(1), $28-49$.

Chukwuemeka, E. (2011). The challenges of government policy on entrepreneurship in Nigeria. The Journal of Commerce, 3(2), 11.

Cronbach, L. (1951). Coefficient alpha and the internal structure of tests. Psychometrika, 16(3), 297-334.

Curran, J. (2000). What is small business policy in the UK for? Evaluating and assessing small business policies. International Small Business Journal, 18(3), 36-50.

Desy, P. L. (2018). History or Fable of the Praying Hands Masterpiece. https://www.thoughtco.com/praying-hands-1725186

Doing Business Report (2018). A World Bank Group flagship Report. Retrieved 24 April, 2018 from www.doingbusiness.org

Ene, E. E., \& Ene, J. C. (2014). Financing small and medium scale business in African countries: Problems and prospects. Australian Journal of Business and Management Research, 4(6), 9.

Ezedinma, C. (2008). Impact of trade on domestic rice production and the challenge of self sufficiency in Nigeria. Rice Policy and Food Security in sub-Saharan Africa, 141.

Fatai, A. (2011). Small and medium scale enterprises in Nigeria: The problems and Prospects Retrieved September 6 from www.thecje.com/journal/index.php/economicsjour nal/article/.../8.

Fattoum, S., \& Fayolle, A. (2009). Generational succession: Examples from Tunisian family firms. Journal of Enterprising Culture, $17,127-145$.

Fitzgerald, R. (2005). Products, firms and consumption: Cadbury and the development of marketing, 1900-1939. Business History, 47(4), 511-531.

Gilbert, B. A., Audretsch, D. B., \& McDougall, P. P. (2004). The emergence of entrepreneurship policy. Small Business Economics, 22(3), 313-323.

Global Entrepreneurship Development Index (2014). Entrepeneurship index. Retrieved $8^{\text {th }}$ September, 2017 from https:// thegedi.org/research/gedi-index/

Kelley, D. J., Singer, S., \& Herrington, M. (2011). The global entrepreneurship monitor: 2011. World Report, 1-39.

Kiabel, B. D., \& Nwokah, N. G. (2009). Curbing tax evasion and avoidance in personal income tax administration: A study of the south-south states of Nigeria. European Journal of Economics, Finance and Administrative Sciences, 15(1), 16-61.

Klapper, L., Amit, R., \& Guillén, M. F. (2010). Entrepreneurship and firm formation across countries. In International differences in entrepreneurship (pp. 129-158). University of Chicago Press.

Kreft, S. F., \& Sobel, R. S. (2005). Public policy, entrepreneurship, and economic freedom. Cato J, 25, 595.

Ladzani, W. M., \& Van Vuuren, J. J. (2002). Entrepreneurship training for emerging SMEs in South Africa. Journal of Small Business Management, 40(2), 154-161. 
Larossi, G., \& Clarke, G. R. (2011). Nigeria 2011: An assessment of the investment climate in 26 states. Washington DC: World Bank. Lerner, J., \& Kegler, C. (2000). Evaluating the Small Business Innovation Research Program: A Literature Review. The Small Business Innovation Research Program: An Assessment of the Department of Defence Fast Track Initiative, 307-324.

Ligthelm, A. (2005). Measuring the size of the informal sector in South Africa, 2004/05 (pp. 1- 94). Pretoria: Bureau of Market Research, University of South Africa.

Ligthelm, A. A. (2006). Size estimate of the informal sector in South Africa. South African Business Review, 10(2), 32-53.

Lin, G. T., Chang, Y., \& Shen, Y. (2010). Innovation policy analysis and learning: Comparing Ireland and Taiwan. Entrepreneurship \& Regional Development, 22, 731-762.

Makinde, T. (2005). Problems of policy implementation in developing nations: The Nigerian experience. Journal of Social sciences, 11(1), 63-69.

Mary, O. E., Enyinna, U. K., \& Ukpai, K. A. (2015). The effect of policy measures on entrepreneurship development analysis of Nigeria's experience. European Journal of Business and Management, 7(19), 43-49.

Mbonyane, B., \& Ladzani, W. (2011). Factors that hinder the growth of small businesses in south African townships. European Business Review, 23(6), 550-560.

Morris, M. H., Williams, R. O., Allen, J. A., \& Avila, R. A. (1997). Correlates of success in family business transitions. Journal of business venturing, 12(5), 385-401.Morris, M. H., Williams, R. O., Allen, J. A., \& Avila, R. A. (1997). Correlates of success in family business transitions. Journal of business venturing, 12(5), 385-401.

Ngerebo, T. A., \& Masa, A. (2012). Appraisal of tax system in Nigeria (a case study of value added tax). Research Journal in Organizational Psychology and Educational Studies, 1(6), 338-344.

Nieman, G. (2001). Training entrepreneurs and small business Enterprises in South Africa: A situational analysis. Education \& Training, 43(8/9), 445-450.

Odusola, A. (2006). Tax policy reforms in Nigeria (No. 2006/03). Research Paper, UNU-WIDER, United Nations University (UNU).

Olawale, F., \& Garwe, D. (2010). Obstacles to the growth of new SMEs in South Africa: A principal component analysis approach. African Journal of Business Management, 4(5), 729-738.

Oliyide, O. (2012). Law, credit risk management and Bank lending to SMEs in Nigeria. Commonwealth Law Bulletin, 38(4), 673-695.

Otusanya, O. J. (2010). An investigation of tax evasion, tax avoidance and corruption in Nigeria. The University of Essex: Doctoral dissertation.

Oviatt, B. M., \& McDougall, P. P. (2005). Defining international entrepreneurship and modelling the speed of internationalization. Entrepreneurship Theory \& Practice, 29(5), 537-553.

Oyejide, T. A. (1986). The effects of trade and exchange rate policies on agriculture in Nigeria. International Food Policy Research Institute, (55), 1-61.

RSA. (1996). National Small Business act no. 102 of 1996. In Republic of South Africa government gazette.

Santos, J. R. A. (1999). Cronbach's alpha: A tool for assessing the reliability of scales. Journal of Extension, 37, 2.

Singh, S., Simpson, R., Mordi, C., \& Okafor, C. (2011). Motivation to become an entrepreneur: A study of Nigerian Women's decisions. African Journal of Economic and Management Studies, 2(2), 202-219.

Smith, A. (1776). The wealth of nations. London: W. Strahan and T. Cadell.

Tijani, A. A., Oyeniyi, G. O., \& Ogunyomi, O. O. (2012). The impact of technical entrepreneurial skills on employment generation in small and medium scale Enterprises in Lagos State, Nigeria: A comparative analysis. European Journal of Humanities and Social Sciences, 13(1)

Today, Ng News Bulletin retrieved online on the $25^{\text {th }}$ April 2018 from https://www.today.ng/tag/government-enterprise-andempowerment-programme

Urban, B. (2009). Opportunity recognition: Delineating the process and motivators for serial entrepreneurs. South African Journal of Economic and Management Sciences, 12(4), 513-532.

Vesper, K. H. (1983). Entrepreneurship and national policy (Vol. 3). Walter E. Heller International Corporation Institute for Small Business.

Ward, J. L. (2004). Growing the family business: Special challenges and best practices. Family Business Review, 10(4), $323-337$.

Wold, S., Esbensen, K., \& Geladi, P. (1987). Principal component analysis. Chemometrics and Intelligent Laboratory Systems, 2(1-3), 37-52

Wright, M., Westhead, P., \& Ucbasaran, D. (2007). Internationalisation of small and medium-sized enterprises (SMEs) and international entrepreneurship: A critic of policy implications. Regional Studies, 41(7), 1013-1030.

Zolin, R. (2012). Unsung heroes: African Americans and entrepreneurship. Encyclopedia of New Venture Management, 11-16.

\section{Submit your manuscript to a SpringerOpen ${ }^{\circ}$ journal and benefit from:}

- Convenient online submission

- Rigorous peer review

- Open access: articles freely available online

- High visibility within the field

- Retaining the copyright to your article

Submit your next manuscript at $\boldsymbol{\nabla}$ springeropen.com 